\title{
Mini-flared Kelman tip, reverse tip, and sidewinder tip with torsional phaco: a prospective randomized comparative study
}

\author{
Faco torsional utilizando as ponteiras Kelman mini-flared, reversa e sidewinder: \\ um estudo prospectivo comparativo randomizado
}

Wilson Takashi Hida ${ }^{1}$, Patrick Frensel Tzelikis ${ }^{1}$, Celso Takashi Nakano², Antonio Francisco Pimenta Motta², Milton Ruiz Alves²

\begin{abstract}
Purpose: To compare the efficiency of surgical procedures using three phaco tip designs in torsional phacoemulsification using the bevel-down technique.

Methods: In this prospective, comparative, masked study, patients were randomly assigned to have torsional coaxial microincision cataract surgery using the mini-flared 45-degree Kelman tip, reversed mini-flared 30-degree Kelman tip, or Sidewinder 30-degree Kelman tip. Clinical measurements included preoperative and 3-month postoperative corrected distance visual acuity (CDVA), endothelia cell counts (ECC), and preoperative and 1-day postoperative central corneal thickness (CCT). Intraoperative measurements included phaco time, torsional time, aspiration time, case time, cumulative dissipated energy (CDE), and balanced salt solution volume (BSS).

Results: The study evaluated 150 eyes of 150 patients. Intraoperatively, there was no statistically significant difference in cumulative dissipated energy, case time, torsional time, and aspiration time between the three tip configurations. However, less phaco time was used with the mini-flared 45 -degree Kelman tip $(p=0.02)$ than that with the Sidewinder 30-degree Kelman tip or reversed mini-flared 30-degree Kelman tip. The mini-flared 45-degree Kelman tip and the reversed mini-flared 30-degree Kelman tip required significantly less balanced salt solution volume than that required by the Sidewinder 30-degree Kelman tip $(p=0.009)$. There was no statistically significant difference in corrected distance visual acuity and endothelial cell counts between tips 3 months postoperatively $(p>0.05)$

Conclusion: All three tips were effective with no intraoperative complications. When using torsional phacoemulsification through microincisions and the prefracture technique with the bevel-down technique, the mini-flared 45-degree Kelman tip required a lower mean phaco time than the reversed mini-flared 30-degree Kelman tip and the Sidewinder 30-degree Kelman tip.
\end{abstract}

Keywords: Phacoemulsification/methods; Cataract extraction; Drainage/instru mentation; Equipment design; Cell count; Endothelium, corneal; Visual acuity; Prospective studies

\section{RESUMO}

Objetivo: Compararaeficáciacirúrgica da facoemulsificaçãocom tecnologia torcional utilizando 3 modelos diferentes de ponteiras.

Métodos: Neste estudo prospectivo, randomizado, mascarado, os pacientes foram aleatoriamente distribuidos para serem submetidos a cirurgia de facoemulsificação coaxial torcional utilizando a ponteira Kelman mini-flared de 45 graus, ou Kelman reversed mini-flared de 30 graus ou Kelman Sidewinder de 30 graus. Os parâmetros avaliados incluíram: acuidade visual com correção (AVCC) para longe; contagem de células endoteliais (CCE) pré-operatória e pós-operatória, ao final de 3 meses; espessura corneana central (ECC) pré-operatória eno primeiro dia pós-operatório. Medidas intraoperatórias incluíram tempo de facoemulsificação, tempo de energia torcional, tempo da aspiração, tempo cirúrgico, energia dissipada acumulada (CDE) e volume de solução salina balanceada (BSS).

Resultados: Este estudo avaliou 150 olhos de 150 pacientes. No intraoperatório, não foram observadas diferenças significativas na energia dissipada acumulada, tempo de facoemulsificação, tempo de energia torcional, e tempo de aspiração entre os 3 modelos de ponteira. No entanto, foi utilizando menos tempo de faco com a ponteira Kelman mini-flared de 45 graus $(p=0,02)$ quando comparado às ponteiras Kelman Sidewinder de 30 graus e reversa mini-flared de 30 graus. A ponteira Kelman mini-flared de 45 graus e a reversa mini-flared de 30 graus utilizaram menos solução salina balanceada quando comparado à ponteira Sidewinder de 30 graus $(p=0,009)$. Não foram observadas diferenças significativas na acuidade visual com correção, contagem de células endoteliais e espessura corneana central entre as diferentes ponteiras ao final do estudo $(p=0,05)$.

Conclusão: As 3 ponteiras foram eficazes enão apresentaram complicacões intraoperatórias. Quando foi utilizando o faco torcional através de microincisão com a técnica da pré-fratura, a ponteira Kelman mini-flared de 45 graus obteve um desempenho melhor que as ponteiras de 30 graus e Sidewinder de 30 graus, com menor tempo de faco.

Descritores: Facoemulsificação/métodos; Extração de catarata; Drenagem/instrumentação; Desenho de equipamento; Contagem de células; Epitélio posterior; Acuidade visual; Estudos prospectivos

\section{INTRODUCTION}

Since the 1970's, endothelial cell loss remains a serious concern regarding a successful outcome of cataract surgery. Corneal endothelial damage during surgery is inevitable, and can be influenced by several preoperative and intraoperative parameters. Preoperative parameters include older age, constricted pupil, firmness of the nucleus, and shorter axial length $(\mathrm{AL})^{(1-2)}$. Intraoperative factors include the incision size and design, Descemet membrane detachment, toxic intraoperative medications, phacoemulsification technique, and the type of ophthalmic viscosurgical device (OVD) used $\mathrm{d}^{(1-4)}$.
Mechanisms proposed for endothelial cell damage during phacoemulsification include turbulence and movement of fluids, direct trauma caused by instruments or lens fragments, total amount of ultrasound (US) energy used, US energy dissipated close to the corneal endothelium, intraoperative complications (e.g. presence of air bubbles, release of free radicals), low surgeon experience, and postoperative inflammation ${ }^{(3-6)}$.

To reduce the energy applied, aspects related to the phacoemulsifier such as ultrasound modes, special tips, microprocessors, and high-vacuum systems must be considered. In the hands of an expe- 
rienced surgeon, the total amount of US energy and the hydrodynamic flow in the anterior chamber are presumed to be the main damaging factors to corneal endothelial cells in phacoemulsification ${ }^{(1)}$. To reduce the amount of total US energy dissipated in the eye, some surgeons use high hydrodynamic parameters (vacuum and flow rate) to accelerate surgery ${ }^{(7)}$. Several new phacoemulsification strategies and new devices were developed to preserve the corneal endothelium by attenuating the deleterious effects of US ${ }^{(8)}$. Some surgeons have attempted to alleviate the corneal load by varying the position of the phacoemulsification tip ${ }^{(4,9)}$.

The purpose of this study was to compare intraoperative and clinical parameters using the mini-flared 45-degree Kelman tip (Alcon Laboratories, Inc.), the reversed mini-flared 30-degree Kelman tip (Alcon Laboratories, Inc.), and the Sidewinder 45-degree Kelman tip (Mastel Precision Surgical, Inc.).

\section{METHODS}

\section{Patient enrollment}

This was a prospective, comparative, randomized, patient-masked study. A computer-generated randomization list was used to assign the phacoemulsification cases to one of three groups with different tip configurations: the mini-flared 45-degree Kelman tip, the reversed 30-degree tip, and the Sidewinder 45-degree Kelman tip, which was specially sharpened on both sides in order to increase the efficiency of torsional phaco (Figure 1).

The study complied with established ethical standards for clinical research from the Institutional Review Board (IRB) of the Brasilia Ophthalmologic Hospital (HOB) in Brazil, and conducted between November 2010 and February of 2011. All surgeries were performed at the HOB. Physicians conducting postoperative evaluation did not have access to patients' medical records. Exclusion criteria were previous ocular surgery, central endothelial cell count less than 2000 cells $/ \mathrm{mm}^{2}$, glaucoma or intraocular pressure greater than $21 \mathrm{mmHg}$, amblyopia, retinal abnormalities, steroid or immunosuppressive treatment, and connective tissue diseases. Enrolled patients were excluded if they had complicated cataract surgery (e.g. posterior capsule rupture, vitreous loss, or an intraocular lens not placed in the capsular bag).

\section{SURGICAL TECHNIQUE}

Surgeries were performed by a senior surgeon (WTH), who had used torsional mode with bevel-down technique in more than 15,000 cases with the same prefracture with preslice and prechop technique. All patients received topical anesthesia with lidocaine $2 \%$ gel before surgery. A $2.2 \mathrm{~mm}$ self-sealing clear corneal incision on the steepest meridian axis was created. We used a viscoelastic solution of sodium hyaluronate 3\% and chondroitin sulfate 4\% (Viscoat; Alcon Laboratories, Fort Worth, Texas, USA) to reform and stabilize the surgical planes, and to protect the endothelium. A 5.00 to $5.25 \mathrm{~mm}$ continuous curvilinear capsulorhexis was completed with Utrata forceps. We used the Akahoshi Phaco PreChopper (ASICO Products, Inc.) to fracture the nucleus in half, and removed the nucleus by phacoemulsification using the Infinite Ozil Vision System (Alcon Surgical) device. The tip of the phaco handpiece was positioned face down during phacoemulsification. The phaco settings were identical in all cases: torsional ultrasound at 20 pulse per second (minimum amplitude of 20\%, maximum $80 \%$ and time on 85\%), longitudinal power at zero, $100 \mathrm{~cm}$ irrigation bottle height, minimum 70 and maximum $350 \mathrm{mmHg}$ linear vacuum, aspiration flow rate $30 \mathrm{cc} / \mathrm{min}$, dynamic rise zero, and Ozil IP settings 1.0, with $10 \mathrm{~ms}$ and $95 \%$ power. After cortical aspiration, the IOL was placed in the bag with careful centration using the Royale $^{\circledR}$ (Asico, Chicago, CA, USA) or Emerald ${ }^{\circledR}(A M O$, Santa Anna, CA, USA) delivery system.

\section{StUdY PROTOCOL}

Preoperative Lens Opacities Classification System III (LOCS III) ${ }^{(10)}$ grading was done using a slit lamp (Topcon, SL 1E) microscope after dilating the pupil with a combination of topical tropicamide $1.0 \%$ and phenylephrine $2.5 \%$. Nuclear opacity was graded according to nuclear opalescence (NO) and nuclear color (NC) on a scale of 0.1 to 6.9 by the same ophthalmologist. Cataract was graded using the software on the Oculus Pentacam, the Pentacam Grading System (PNS), to measure the optical density of the nucleus.

Preoperative examinations included logMAR corrected distance visual acuity (CDVA) with the early treatment of diabetic retinopathy study (ETDRS) chart, central corneal thickness (CCT) (Ocuscan Rxp, Alcon Laboratories), and endothelial cell count (ECC) (Konan Medical).

Intraoperative measurements included cumulative dissipated energy (CDE), phaco time, torsional time, aspiration time, case time, and the amount of balanced salt solution (BSS) used. The mean CDE is the mean percentage of power spent during US and is calculated in torsional mode (torsional amplitude $x$ torsional time $x 0.4$ ). It was automatically calculated and displayed on the monitor of the phaco machine.

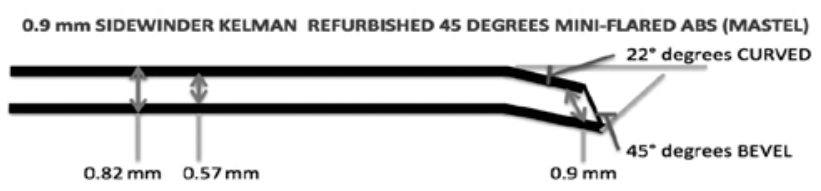

$0.9 \mathrm{~mm}$ KELMAN 45 DEGREES MINI-FLARED ABS (ALCON LABS)

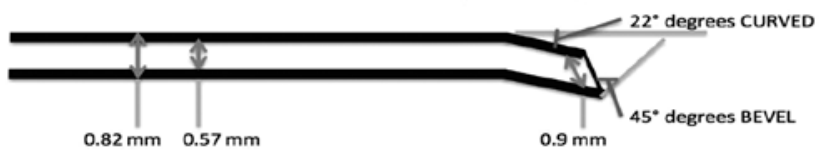

$0.82 \mathrm{~mm} \quad 0.57 \mathrm{~mm}$ $0.9 \mathrm{~mm}$

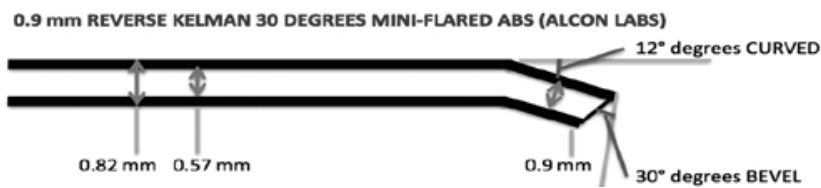

Figure 1. The Kelman-configuration tips used in this study.
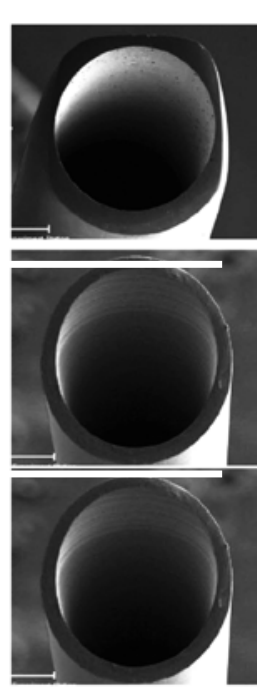
Table 1. Preoperative patient characteristics

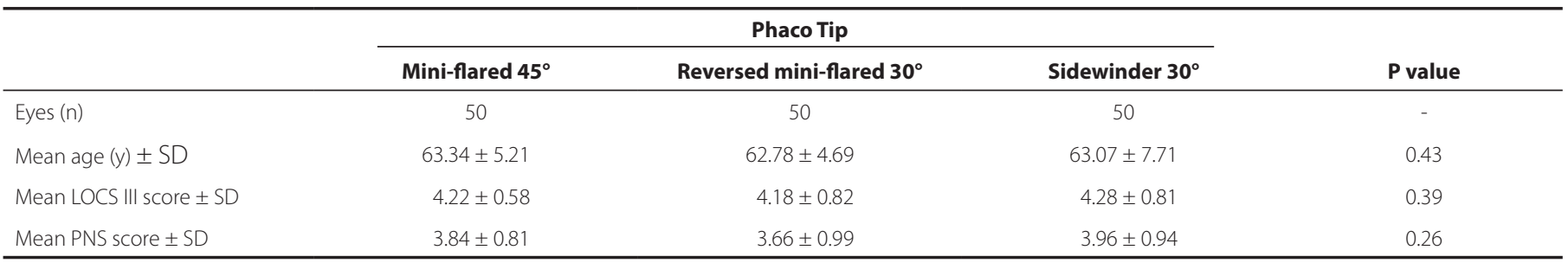

LOCS III= lens opacities classification system III; PNS= pentacam nucleus score (cataract grading system).

\section{Table 2. Clinical and intraoperative results}

\begin{tabular}{|c|c|c|c|c|}
\hline & \multicolumn{3}{|c|}{ Mean \pm SD } & \multirow[b]{2}{*}{ P Value } \\
\hline & Mini-flared $45^{\circ}$ & Reversed mini-flared $30^{\circ}$ & Sidewinder $30^{\circ}$ & \\
\hline \multicolumn{5}{|l|}{ CDVA (LogMAR) } \\
\hline Preoperative & $0.31 \pm 0.15$ & $0.34 \pm 0.13$ & $0.33 \pm 0.12$ & 0.08 \\
\hline 3 months postop & $0.03 \pm 0.05$ & $0.03 \pm 0.05$ & $0.03 \pm 0.04$ & 0.88 \\
\hline Change & $0.28 \pm 0.16$ & $0.35 \pm 0.15$ & $0.30 \pm 0.12$ & 0.08 \\
\hline \multicolumn{5}{|l|}{$\mathrm{CCT}(\mu \mathrm{m})$} \\
\hline Preop & $550.26 \pm 25.43$ & $543.86 \pm 25.12$ & $559.66 \pm 39.04$ & 0.06 \\
\hline 1 day postop & $579.06 \pm 27.50$ & $569.92 \pm 31.84$ & $584.28 \pm 40.93$ & 0.10 \\
\hline Change & $28.80 \pm 29.54$ & $26.06 \pm 34.50$ & $24.62 \pm 20.32$ & 0.76 \\
\hline \multicolumn{5}{|l|}{ ECC (cells/mm²) } \\
\hline Preop & $2597.28 \pm 87.50$ & $2561.72 \pm 44.57$ & $2563.26 \pm 99.90$ & 0.06 \\
\hline 3 months postop & $2440.06 \pm 85.17$ & $2402.26 \pm 48.62$ & $2406.86 \pm 92.94$ & 0.06 \\
\hline Change & $157.22 \pm 40.11$ & $159.46 \pm 42.48$ & $156.40 \pm 23.70$ & 0.91 \\
\hline \multicolumn{5}{|l|}{ Intraoperative } \\
\hline CDE & $9.23 \pm 4.49$ & $9.43 \pm 6.52$ & $9.61 \pm 4.81$ & 0.98 \\
\hline BSS used (mL) & $28.50 \pm 12.36$ & $26.68 \pm 9.95$ & $34.28 \pm 14.59$ & 0.009 \\
\hline Case time (sec) & $101.94 \pm 43.99$ & $98.76 \pm 29.82$ & $118.17 \pm 60.40$ & 0.14 \\
\hline Phaco time (sec) & $0.66 \pm 0.67$ & $1.08 \pm 0.82$ & $1.04 \pm 0.87$ & 0.02 \\
\hline Torsional time (sec) & $36.99 \pm 15.84$ & $35.83 \pm 18.53$ & $41.07 \pm 15.81$ & 0.07 \\
\hline Aspiration time (sec) & $65.90 \pm 28.03$ & $64.09 \pm 19.34$ & $65.74 \pm 37.19$ & 0.21 \\
\hline
\end{tabular}

$C D V A=$ corrected distance visual acuity; $C C T=$ central corneal thickness; $E C C=$ endothelial cell count; $C D E=$ cumulative dissipated energy; $B S S=$ balanced salt solution.

The postoperative examination included CDVA, CCT, and ECC and was performed at 1 day and approximately at 3 months after the surgery.

\section{Statistical analysis}

We used SPSS Statistics (version 17.0, SPSS, Inc., Chicago, Illinois, USA) for all data analyses, using analysis of variance (ANOVA). We tested group differences in parameters using 1-way ANOVA, and used the Levene statistic to test the equality of group variances in the 1-way ANOVA. We tested multiple comparisons using the Tukey test when the group variances were equal pairwise and the Tamhane test when they were unequal. Differences were considered statistically significant when the $P$ value was less than 0.05 .

\section{RESULTS}

The study included 150 eyes of 150 patients, 83 (55\%) patients were women. The mean patient age was 62.54 years \pm 5.81 (SD) (range 45 to 85 years). Table 1 shows the preoperative patient characteristics by phaco tip and by the LOCS III and PNS cataract grading systems. The mean LOCS III score was $4.29 \pm 0.43$; the mean Scheimpflug-measured lens nuclear density was $3.82 \pm 0.44$. There were no statistically significant differences in age or sex between the three phaco-tip groups.

Table 2 shows the intraoperative and postoperative results. No intraoperative complications were observed. The improvement in CDVA was similar in all groups. There were no statistically significant differences in the change in CCT (1-day postoperative CCT minus preoperative CCT) $(p=0.76)$ or the change in ECC (3-month postoperative ECC minus preoperative ECC) $(p=0.91)$ between the three tips.

When comparing CDE, case time, torsional time and aspiration time, there were no statistically significant differences between any of the tips (Table 2).

The phaco time was statistically significantly less with the 45-degree Kelman tip than with the Sidewinder 30-degree Kelman tip and the reversed mini-flared 30-degree Kelman tip ( $p=0.02)$. The mini-flared 45-degree Kelman tip and the reversed mini-flared 30-degree Kelman tip required significantly less BSS than the Sidewinder 30-degree Kelman tip ( $p=0.009$, Table 2 ). 


\section{DISCUSSION}

Over the years, there have been significant advances in cataract surgery. Improvements in control of phacoemulsification tip stroke amplitude, modulation of US "on" time via burst and pulse modes, and improved control of vacuum, postocclusion surge and aspiration flow rate have allowed cataract surgical techniques to evolve to high levels of efficiency ${ }^{(11)}$. Although many studies of phacoemulsification techniques have been published, much less is published about the hardware (tips) used in the procedure. Textbooks primarily discuss various bevel angles and shapes without providing outcome data ${ }^{(12)}$. Advances in phacoemulsification surgery with different phaco microtips, sleeves, and torsional movement have resulted in a very effective procedure for patients, providing faster visual recovery and earlier return to routine daily activities ${ }^{(13)}$.

Higher US power (cumulative dissipated energy) and longer phaco times have been implicated in endothelial cell loss ${ }^{(14,15)}$. O'Brien et al. ${ }^{(14)}$ found a significant association between phaco time, mean US power, and endothelial cell loss. Dick et al. ${ }^{(15)}$ found a significant correlation between phaco time and central endothelial cell loss, but not between phaco energy and cell loss. Other studies found no correlation ${ }^{(16,17)}$. In the present study, we compared clinical and intraoperative parameters of three phaco tips designs in torsional phacoemulsification using the bevel-down technique: the Sidewinder 30-degree Kelman tip, the mini-flared 45-degree Kelman tip, and the reversed mini-flared 30-degree Kelman tip. There was a statistically significant difference in phaco time and BSS used between the mini-flared 45-degree Kelman tip and the Sidewinder 30-degree Kelman tip and reversed mini-flared 30-degree Kelman tip. However, there was no significant correlation between these parameters and endothelial cell loss. In addition, the cell loss was not significantly different between the tips.

The mean phaco time differed between tips. The mini-flared 45-degree Kelman tip required the least phaco time (0.66 seconds), the reversed mini-flared 30-degree Kelman tip required the most (1.08 seconds). The difference is statistically significant $(p=0.02)$. The effectiveness of phacoemulsification depends on the proportion of applied US energy and fluid exchange in the anterior chamber during removal of nuclear material. During phacoemulsification, a hard nucleus requires more US energy than a soft nucleus. Therefore, the energy recorded as the CDE reflects the efficacy of the tips. In our study, there was no statistical difference between the three groups when comparing $C D E$, case time, torsional time and aspiration time. Kim et al. ${ }^{(18)}$ published a similar report comparing the mini-flared 30-degree Kelman tip, mini-flared 45-degree Kelman tip, and reverse mini-flared 30-degree Kelman tip in torsional phacoemulsification cases, also using the bevel-down technique. In their study, the CDE use was statistically significantly less with the 45-degree Kelman tip and the reverse 30 -degree Kelman tip than with the 30-degree Kelman tip $(p<0.05)$, with no significant differences in CDE use between the 45 -degree Kelman tip and the reverse 30-degree Kelman tip. No case time, phaco time, torsional time and aspiration time were measured intraoperatively.

We verified that the mini-flared 45-degree Kelman tip and the reversed mini-flared 30-degree Kelman tip required significantly less BSS than the Sidewinder 30-degree Kelman tip $(28.50 \mathrm{~mL}$ and $26.68 \mathrm{~mL}$ versus $34.28 \mathrm{~mL} ; \mathrm{P}=0.009$ ). The volume of fluid used has been implicated as a risk factor for corneal endothelial damage, because irrigation flow and turbulence within the anterior chamber may compromise the glycoprotein coat of the endothelium and induce stress ${ }^{(19)}$. Whether the increased risk for endothelial damage is related to fluidic principles or simply to the fact that volume infused is a surrogate measure of needle time is unclear ${ }^{(20)}$.

Regarding study weakness, the first limitation of this study is surgeon bias. Although there is a possibility that the surgeon knew which tip he was using during each surgery, he tried to use his normal phacoemulsification technique without variation for each surgery, regardless of tip. A second limitation is the small number of cases analyzed. Although higher case numbers might be preferred, analysis of the differences between sample means for tips was shown to be statistically significant. A third limitation is that we did not divide the cases into groups based on the nuclear opacity grade. We might observe different results with moderate to severe nuclear density.

\section{CONCLUSION}

Our data shows that to minimize fluid use and ultrasound energy with the prefracture technique, the mini-flared 45 degrees Kelman tip was the most efficient, requiring less phaco time and BSS. The CDVA results were similar between tips, showing that all tips configurations are safe and homogeneous, leading to fast rehabilitation and good visual quality. Additional research of phaco tips should contribute to improving the efficiency of various surgical approaches. Further studies are needed to evaluate the tip cutting geometry and the effect of refurbishing.

\section{REFERENCES}

1. Hayashi K, Hayashi H, Nakao F, Hayashi F. Risk factors for corneal endothelial injury during phacoemulsification. J Cataract Refract Surg. 1996;22(8):1079-84.

2. Walkow T, Anders N, Klebe S. Endothelial cell loss after phacoemulsification: relation to preoperative and intraoperative parameters. J Cataract Refract Surg. 2000;26(5):727-32.

3. Pirazzoli G, D'Eliseo D, Ziosi M, Acciarri R. Effects of phacoemulsification time on the corneal endothelium using phacofracture and phaco chop techniques. J Cataract Refract Surg. 1996;22(7):967-9.

4. Faramarzi A, Javadi MA, Karimian F, Jafarinasab MR, Baradaran-Rafii A, Jafari F, et al. Corneal endothelial cell loss during phacoemulsification: bevel-up versus bevel-down phaco tip. J Cataract Refract Surg. 2011;37(11):1971-6. Comment in: J Cataract Refract Surg. 2012;38(6):1113-4; author reply 1114; J Cataract Refract Surg. 2012;38(6):1114-5; author reply 1115; J Cataract Refract Surg. 2012; 38(6):1113; author reply 1113.

5. Vargas LG, Holzer MP, Solomon KD, Sandoval HP, Auffarth GU, Apple DJ. Endothelia cell integrity after phacoemulsification with 2 different handpieces. J Cataract Refract Surg. 2004:30(2):478-82.

6. Fine IH, Packer M, Hoffman RS. Use of power modulations in phacoemulsification: choo-choo chop and flip phacoemulsification. J Cataract Refract Surg. 2001;27(2): 188-97. Comment in: J Cataract Refract Surg. 2001;27(2):175.

7. Díaz-Valle D, Benítez del Castillo Sánchez JM, Castillo A, Sayagués O, Moriche M Endothelial damage with cataract surgery techniques. J Cataract Refract Surg. 1998; 24(7):951-5.

8. Payne M, Georgescu D, Waite AN, Olson RJ. Phacoemulsification tip vacuum pressure: comparison of 4 devices. J Cataract Refract Surg. 2006;32(8):1374-7.

9. Frohn A, Dick HB, Fritzen CP. Corneal impact of ultrasound and bevel position in phacoemulsification. J Cataract Refract Surg. 2002;28(9):1667-70.

10. Chylack LT Jr, Wolfe JK, Singer DM, Leske MC, Bullimore MA, Bailey IL, et al. The Lens Opacities Classification System III. The Longitudinal Study of Cataract Study Group. Arch Ophthalmol. 1993;111(6):831-6.

11. Hoffman RS, Fine $1 \mathrm{H}$, Packer M. New phacoemulsification technology. Curr Opin Ophthalmol. 2005;16(1):38-43.

12. Packer M, Fishkind WJ, Fine $I H$, Seibel BS, Hoffman RS. The physics of phaco: a review. J Cataract Refract Surg. 2005;31(2):424-31.

13. Alio J, Rodriguez-Prats JL, Galal A, Ramzy M. Outcomes of microincision cataract surgery versus coaxial phacoemulsification. Ophthalmology. 2005;112(11):1997-2003. Comment in: Ophthalmology. 2006; 113(9):1687; author reply 1687.

14. O'Brien PD, Fitzpatrick P, Kilmartin D, Beatty S. Risk factors for endothelial cell loss after phacoemulsification surgery by a junior resident. J Cataract Refract Surg. 2004; 30(4):839-43.

15. Dick HB, Kohnen T, Jacobi FK, Jacobi KW. Long-term endothelial cell loss following phacoemulsification through a temporal clear corneal incision. J Cataract Refract Surg. 1996;22(1):63-71.

16. Kosrirukvongs P, Slade SG, Berkeley RG. Corneal endothelial changes after divide and conquer versus chip and flip phacoemulsification. J Cataract Refract Surg. 1997;23(7):1006-12. Comment in: J Cataract Refract Surg. 1997;23(7):967-8.

17. Zetterström C, Laurell CG. Comparison of endothelial cell loss and phacoemulsification energy during endocapsular phacoemulsification surgery. J Cataract Refract Surg. 1995:21(1):55-8.

18. Kim EK, Jo KJ, Joo CK. Comparison of tips in coaxial microincision cataract surgery with the bevel-down technique. J Cataract Refract Surg. 2011;37(11):2028-33. Comment in: J Cataract Refract Surg. 2012;38(5):925-6.

19. The resiliency of the corneal endothelium to refractive and intraocular surgery. EdeIhauser HF. Cornea. 2000;19:263-73. Comment in: Am J Ophthalmol. 2000;130(3):384

20. Baradaran-Rafii A, Rahmati-Kamel M, Eslani M, Kiavash V, Karimian F. Effect of hydrodynamic parameters on corneal endothelial cell loss after phacoemulsification. J Cataract Refract Surg. 2009;35(4):732-7. Comment in: J Cataract Refract Surg. 2009; 35(12): 2178; author reply 2178-9. 